\title{
The Ethos of Transcendence (1965-1977): Decision and the Moral Imperative as Anticipatory Response to Postmodernism
}

\author{
The Philosophical Afterlife of The End of the World: Enzo Paci's \\ Existentialist Historicism and the Moral Imperative Grounded \\ in the Contemporaneity of History
}

Since de Martino passed away in 1965, after a short but serious illness, he was never able to complete his ambitious project about the apocalypse that he envisioned since the beginning of the 196os. Instead, his results were collected in the form of references, notes, and outlines, before being published by Angelo Brelich, his colleague at the University of Rome, and Clara Gallini, one of his last collaborators at the University of Cagliari. Initially, the posthumous publication of de Martino's notes in the form of The End of the World in 1977 gave rise to primarily critical voices that not only questioned the radical rupture with the Southern Period, but also reprimanded him for a lack of clarity during his final years. The best example of this tendency is Vittorio Lanternari's "Between Historicism and Ontology" (1978), in which he charged de Martino's final work of being marked by "ambiguities and internal contradictions." Giovanni Jervis (1933-2009), one of the most important Italian psychiatrists and close associate during these last years, likewise noted that the extensive research on desks and in texts, rather than on the ground, were detrimental to his thinking due to the lack "of everyday cases, of forms of life, of the world of life, of human concreteness."

More recently, however, the "crude (incondite) and medleyed (zibaldoniche)"3 pages of de Martino's "fascinating laboratory of research"4 have slowly but

1 Vittorio Lanternari, "Ernesto de Martino fra storicismo e ontologismo," Studi storici 19, no. 1 (1978): 191.

2 A personal email by Jervis is cited by his student. Massimo Marraffa, "Introduzione. Giovanni Jervis: la ricerca della concretezza," in Contro il sentito dire: psicoanalisi, psichiatria e politica, by Giovanni Jervis, ed. Massimo Marraffa (Torino: Bollati Boringhieri, 2014), xxxIv.

3 Giuseppe Galasso, "Alcuni percorsi dello storicismo italiano del secolo XX," in I percorsi dello storicismo italiano nel secondo Novecento, ed. Maurizio Martirano and Edoardo Massimilla (Napoli: Liguori, 2002), 298.

4 Marcello Massenzio, "Senso della storia e domesticità del mondo," in Ernesto De Martino: un'etnopsichiatria della crisi e del riscatto, ed. Roberto Beneduce, Simona Taliani, and Giordana Charuty (Milano: Il saggiatore, 2015), 39.

(C) FLAVIO A. GEISSHUESLER, 2021 | DOI:10.1163/9789004457720_009

This is an open access chapter distributed under the terms of the CC BY-NC-ND 4. license 
steadily been recovered as a philosophical treasure trove with a broader scope than he himself would have imagined. ${ }^{5}$ One of the most relevant aspects of The End of the World, which has since been republished in Italian (2002), and reedited in an entirely new version in French (2016), ${ }^{6}$ is de Martino's intuition that postmodernism can be seen as a portent of the apocalypse of Western civilization. Specifically, his final reflections warn that the cultural-discursive paradigm is nothing less than "a mask for a limitless abdication,"7 which brings with it the risk of an "apocalypse without eschaton." This "postmodern" sense of an ending, according to de Martino was the apocalypse "without eschaton" because it is a crisis that no longer gives way to a palingenetic opening towards a new future but leads instead to inevitable collapse, destruction, and destabilization. In this sense, it can be regarded as the most radical consequence of the modernization, secularization, and scientification that unfolded over the previous centuries. Whereas earlier civilizations operated along the lines of mythical and ritual conceptions of time, marked by cyclical temporality according to which the end of the world inaugurated a new beginning, in the Western world of the twentieth century a new type of apocalypse emerged on the horizon. De Martino was profoundly aware of both the immeasurable value and the tremendous risk involved in the Western telos. A culture that is premised on autonomous human actions and choices without metahistorical narratives knows no limits while simultaneously always being exposed to the possibility of its ending. In order to clarify what can be described as productive and unproductive forms of the apocalypse, de Martino introduces a distinction between the end of "the world," and the end of " $a$ world."

There is nothing pathological about the end of "a" world. On the contrary, it is a wholesome experience connected to the historicity of the human condition. The world of childhood ends and that of adolescence starts; the world of adolescence ends and that of maturity starts; the world of maturity ends and that of old age starts. With the nuptials, in our society, the newlyweds usually abandon their families and start a new life that

5 Galasso, Croce, Gramsci e altri storici; Andrea Binazzi, “Ernesto de Martino," Belfagor 6 (1969): 678-93; Cases, "Introduzione." However, it is noteworthy that the great historians of Italian philosophy have failed to mention the work of de Martino. Eugenio Garin, Cronache di filosofia italiana (Bari: Laterza, 1966); Antonio Santucci, Esistenzialismo e filosofia italiana (Bologna: Il mulino, 1967).

6 Ernesto De Martino, La fin du monde: essai sur les apocalypses culturelles, ed. Giordana Charuty, Daniel Fabre, and Marcello Massenzio (Paris: EHEss, 2016). This impression of de Martino as a philosopher has further been reinforced by Roberto Pàstina's publication of de Martino's most sophisticated notes in this realm, which appeared as Philosophical Writings in 2005. Ernesto De Martino, Scritti filosofici, ed. Roberto Pàstina (Bologna: Il mulino, 2005).

7 De Martino, La fine del mondo, 281. 
involves the birth of a new world. It is a mixed feeling of tenderness and melancholy that clouds the happiness during the celebration of the new bond and especially at the moment of the definitive detachment. When the people we loved, who were lively and vital parts of our world, are taken from us by death, [...] it seems not only that they vanish with their worlds, but also with ours. Sometimes, the strain is enormous to overcome the crisis of grief and to slowly start up again a new world without them. [In other instances], an age of freedom ends and a period of servitude starts. As much as the loss of the world, in which we were free, may be intolerable and we seek out death, the crisis is overcome (superata) as long as only a little margin of recovery (ripresa) remains - such as the little imperceptible margin that all those who were able to survive the German extermination camps could preserve. Thus, the end of "a" world is part of the order of human cultural history. It is the end of "the" world, inasmuch as the actual experience of the ending of any possible world, which constitutes the radical risk. 8

In the final years of his life, as de Martino grappled with the apocalypse without eschaton, he sought solutions by growing his philosophy into new directions. He not only continued to draw on Croce's historicism, but also on the existentialist philosophy of Enzo Paci (1911-1976). ${ }^{9}$ The two thinkers knew each other well and Paci wrote a review of de Martino's The World of Magic already shortly after its publication in 1948; inserting it within the fold of existentialist thinking. ${ }^{10}$ Later, they formed part of the core writers involved in the early years of Alberto Mondadori's Il Saggiatore publishing house, before Paci came to be "de Martino's most important interlocutor" during the 196os." Unsurprisingly, when de Martino died in 1965, the philosopher was amongst the first voices of commemoration to be heard on the radio. ${ }^{12}$ Just how deep de Martino's appreciation for existentialist thought had grown by that time is also

8 De Martino, La fine del mondo, 630.

9 Sasso, Ernesto de Martino fra religione e filosofia, 363. The most abundant reflections on Paci are to be found throughout de Martino's Philosophical Writings, but there are also some references in The End of the World. De Martino, La fine del mondo, 444, 642ff.

10 Enzo Paci, Il nulla e il problema dell'uomo (Torino: Taylor, 1950).

11 Roberto Pàstina, "Introduzione," in Scritti filosofici, ed. Roberto Pàstina (Bologna: Il mulino, 2005), viII.

12 The transmission took place in 1965, shortly after de Martino's death. Enzo Paci was the moderator and Carlo Levi, Diego Carpitella, and Giovanni Jervis the commentators. It has recently been published: Enzo Paci et al., "Dibattito su Emesto de Martino," in Panorami e spedizioni. Le trasmissioni radiofoniche del 1953-54, by Ernesto De Martino, ed. Luigi M. Lombardi Satriani and Letizia Bindi (Torino: Bollati Boringhieri, 2002), 131-73. 
demonstrated by Vittoria de Palma's emotional account of her partner's passing on the 6th of May, 1965 at the San Camillo hospital in Rome. There, so she tells us, Ernesto asked for the journal Aut Aut on his deathbed, unable to read, he lamented the lack of light in the hospital room shortly before expiring. ${ }^{13} \mathrm{Aut}$ $A u t$, invoking the existential question of "either/or," is the most famous Italian journal dedicated to existentialist philosophy and was founded by none other than Enzo Paci in 1951.

As for Paci, he was another one of those thinkers, who desired to integrate new philosophical influences-in his particular case existentialist philosophy - with the historicist thinking of Benedetto Croce. ${ }^{14}$ Of course, the relationship between these giants of Italian philosophy was anything but harmonious. As Roberts puts it, existentialists like Paci criticized Croce for neglecting individual subjectivity in favor of a positive and optimistic "faith in the overarching rationality of history."15 By contrast, Croce belittled the existentialists for "dwelling on anxiety," arguing that it leads to "morbid selfpreoccupation as opposed to [...] responsible, history-making action."16 This being said, Croce was not immune to crisis and may not have been as serene of a thinker as many commentators have made him out to be. Consider, for instance, The History of Europe (1932), in which he explicitly acknowledged the radical rupture brought about by modernity as it moved away from discerning "life as idyllic [...] and hedonistic" to embrace it in its "dramatic, [...] active, and creative" dimensions. ${ }^{17}$ In this context, we could again draw on the trope of the earthquake in order to point to deeper layers of affinity between existentialists and Croce. Rizi and Moss, for example, have sensitively argued that the hours buried under the rubble, hearing the pleading cries of his dying father, only to be rescued with severe injuries and to find out that he was orphaned at the age of seventeen, left a lasting mark on Croce's thinking. ${ }^{18}$ After emerging out of the ruins of the hotel in Casamìcciola, where he was spending his family summer vacation, Benedetto surfaced as an individual marked by personal crisis, consistent fascination with death, and depressive streaks.

\footnotetext{
13 De Martino, Vita di Gennaro Esposito, Napoletano, 29.

14 Amedeo Vigorelli, L'esistenzialismo Positivo Di Enzo Paci: Una Biografia Intellettuale (19291950) (Milano: F. Angeli, 1987).

15 Roberts, Historicism and Fascism in Modern Italy, 74-76.

16 Roberts, Nothing but History, 100.

17 Croce, Storia d'Europa nel secolo decimonono, 2 o.

18 Myra E. Moss, Benedetto Croce Reconsidered: Truth and Error in Theories of Art, Literature, and History (Hanover: University Press of New England, 1987), 6-7; Fabio Fernando Rizi, Benedetto Croce and Italian Fascism (Toronto: University of Toronto Press, 2003), 13-14. Croce's own account of the events are to be found in Benedetto Croce, Contributo alla critica di me stesso (Napoli: Riccardo Ricciardi, 1918).
} 
From a socio-cultural perspective, as well, existentialism gradually became a force to be reckoned with. While existentialist thinkers initially started out marginalized on the edge of a philosophical spectrum, dominated by the towering figure of anti-fascist thought, they gained momentum after the Second Word War. ${ }^{19}$ Paci was particularly popular because he succeeded at generating a dialogue between two opposed positions. On the one hand, he encouraged his readers to break out of the idealism of Croce by embracing some of the sensibilities of existentialism, a tradition that prides itself of courageously "looking into the face of the irrational, passion and hunger, the dangerous, the precarious, the uncertain, the bad and horror, the nothing and death."20 On the other hand, Paci drew on Croce to critique the German existentialism of the likes of Martin Heidegger for its nihilistic orientation. He explicitly invited his students to follow a Crocean spirit in order to "liberally found one's own finiteness and actualize one's own essence," for man "is himself to the extent that he is faithful to himself: his existing (esistere) is his deciding (decidersi)." ${ }^{21}$

De Martino was deeply inspired by Paci's approach to Crocean philosophy. For him too, Croce was a "solid bastion," ${ }^{22}$ which allowed him to "conquer new intellectual territories," ${ }^{23}$ and to "bring the manifold that is otherwise hard to manage back to a unity, to reduce a plurality of languages into a discursive unity."24 In the notes to The End of the World, de Martino acknowledged that it was "necessary to return to the old Croce, discerning the positive from the negative to reinterpret the theme of the distinction of that which is the most vital and true that it contains."

Croce has taught us that the problem of being is the problem of the distinct operative powers and that outside of this distinction there was nothing else but disintegration. [...] After Croce, it was without a doubt necessary to descend once again into the morass of disintegration. However, not to be swallowed up by it to glorify its threatening waters, but to pull ourselves out from it and to give back new force to a theme

19 Rocco Rubini, The Other Renaissance: Italian Humanism between Hegel and Heidegger (Chicago: University of Chicago Press, 2015), 147-57; Romolo Runcini, "I cavalieri della paura," Passato e presente. Rivista di storia contemporanea 16/17 (1960): 2182-83.

$20 \quad$ Enzo Paci, Esistenzialismo e storicismo (Milano: Mondadori, 1950), 33.

21 Paci, Il nulla e il problema dell'uomo, 33.

22 Mancini, "Postface," 477-78.

23 Carlo Ginzburg, "Genèses de La fin du monde de de Martino," Gradhiva, no. 23 (2016): 201.

24 Carla Pasquinelli, "Quel nomade di de Martino," La ricerca folklorica, no. 13 (April 1, 1986): $57-58$. 
that should not be lost: Being and valorization, existence and transcendence, crisis of the beyond and risk of the nothing, this is the theme. ${ }^{25}$

One of the most important impulses for de Martino's final contribution, a moralistic principle of decision-taking that he defined as the "ethos of transcendence," likely came from Croce's idea of the contemporaneity of history. For the idealist philosopher, already in History: Its Theory and Practice (1917), the contemporaneity of history manifested in an "interest in life," for the "development of culture. Only an interest of the present life," so Croce argued, "can make us investigate a past fact." ${ }^{26}$ Demonstrating his relentless fidelity to this maxim, de Martino also repeatedly referenced Croce's History As the Story of Liberty (1938), arguing that every historical inquiry is always an exploration of the historical situation for better understanding the present moment. ${ }^{27}$

From Croce, de Martino adopted the principle of the contemporaneity of history, but also learned about the continued need to engage in the drama of human history through commitment, decision, and action. In the abovementioned book, published shortly before the outbreak of wwII, Croce discussed moral or ethical will at length. Describing it as a category that comprised the volition of a universal goal, he argued that it expresses itself in political liberty. As Myra Moss notes, "with his description of ethical will, Croce's inventory of the four fundamental activities of consciousness, their interrelations and representations became complete." Even though "intuitions [...] remained autonomous and pure concepts or categories included them in the concrete universality of their conceptual representations," Croce also insisted that "ethical volition, in turn, stimulates new intuitions, which, however, do not explicitly include the former in their expressions." ${ }^{28}$ This being said, for the optimistic historicism of Croce, it was vital that the circle could be conceived as an ever-upward moving spiral. It is here that the moral will received its distinctive importance as it was to ensure that humans lived in ever greater degrees of political liberty. Liberty, so Moss summarizes, "had to be recognized, fought for, and won." ${ }^{29}$ Croce argued that "moral activity" (attività morale) was not just one category amongst many others, but the "struggle against evil" (la

\footnotetext{
25 De Martino, La fine del mondo, 697-98.

26 Benedetto Croce, Teoria e storia della storiografia (Bari: Laterza, 1917), 14.

27 De Martino, Sud e Magia, 183; De Martino, La terra del rimorso, 17.

28 Myra E. Moss, "Benedetto Croce, Historian-Philosopher: Is History Autobiography?," Bollettino Filosofico 28 (2013): 256.

29 Moss, 256.
} 
lotta contro il male), whose task it is to oppose the "fragmentation of the spiritual unity" ( fragmentatione dell'unità spirituale). ${ }^{30}$

In the last ten years of his life, so Silvia Mancini noted, de Martino's ontological conception of humanity, which dominated his earlier writings like The World of Magic, was replaced with an ethical, formal, and spiritual model of thinking. ${ }^{31}$ The overwhelming presence of terms such as "decision" (decisione), "transcendence" (trascendimento), "courage" (corraggio), or "ethos" (ethos) all point to this moralistic turn in de Martino's mature thought. As Giuseppe Galasso put it, despite the fact that "the existentialist thematic seems to assume $[. .$.$] a greater resonance and that the danger of the existential disso-$ lution seems to be amplified in terms of a collective drama," it would be an error to understand him as an "intellectual of crisis." ${ }^{\text {2 } 2}$ De Martino, in fact, was answering what Roberts called Croce's "call to action, a charge of responsibility," as the "ever 'richer' evils" that "come to be as the world grows," provoke consistently a "new ethical response."33

\section{Impossible Nostalgia and the Anticipatory Analysis of the} Discursive Turn

As I have argued in chapter 5 , the path that led our civilization along the socalled "cultural turn" must be understood as a less curvy road than commonly assumed as there exists a clear continuity between cultural relativism and the earlier insider-phenomenological approach. Of course, it would be wrong to speak of a complete identity of the Geertzian cultural-discursive paradigm and the German or Boasian conception of culture. For instance, it is well known that while the early science of hermeneutics represented an apologetic attempt at interpreting biblical texts, ${ }^{34}$ Geertzian interpretative anthropology moved beyond these theological origins. This type of thinking "no longer presupposes explicitly religious metaphors and concerns in its disquisitions. ${ }^{35}$ Instead, so

$30 \quad$ Benedetto Croce, La storia come pensiero e come azione (Bari: Laterza, 1938), 50-52.

31 Mancini, "Postface," 536-42. A similar observation is to be found in Gambardella who calls him a "philosopher of ethics." Fabiana Gambardella, "Book Review: Ernesto de Martino. La fine del mondo.," Scienza e Filosofia, no. 8 (2012): 298.

32 Galasso, Croce, Gramsci e altri storici, 310.

33 Roberts, Historicism and Fascism in Modern Italy, 204.

34 Burkhard Gladigow, "Friedrich Schleiermarcher (1768-1834)," in Klassiker der Religionswissenschaft: von Friedrich Schleiermacher bis Mircea Eliade, ed. Axel Michaels (München: Beck, 1997), 17-28.

Lawson and McCauley, "Crisis of Conscience, Riddle of Identity," 213. 
it has been argued, "it has provided historians of religions with a new guiding metaphor, namely, "The Text." 36 Nonetheless, it must be noted that the centrality of the term "Text," intentionally capitalized in the account of Lawson and McCauley, points to an important parallel between the object of study of the insider-phenomenological and the cultural-discursive scholars. Indeed, amongst latter, the text is oftentimes imbued with an almost religious dimension that strongly resembles the fascination with religious experience of the former current. Geertz, for example, not only identified culture with texts to be read, but also emphasized the essentially religious nature of culture. While religion was admittedly only one part of his cultural system, Geertz "took a keen interest in religion." ${ }^{37}$ Every time he was setting out for his ethnographic explorations - whether this be in Indonesia or in Morocco-Geertz identified religious symbols and beliefs as the marking trait of his studies of their cultures. Unsurprisingly, the books resulting from these ethnographic encounters carry such titles as The Religion of Java (1960) or Islam Observed (1968).

Furthermore, it is hardly a coincidence that Geertz offered one of his most concise definitions of culture in an essay entitled "Religion as a Cultural System." It is here that he spoke of culture as a "pattern of meanings embodied in symbols, a system of inherited conceptions expressed in symbolic forms by means of which men communicate, perpetuate, and develop their knowledge about and attitudes toward life."38 Masuzawa, commenting on this very passage, has noted that one of Geertz's "implicit but obvious assumption here is that the term 'culture,' understood as a system of meaning, is more or less interchangeable with 'a tradition,' 'a religious tradition,' or simply, 'a religion."'39 Similarly, Marc Augé has pointed to the fact that such a conception of culture has much in common with the Romantic-nostalgic versions explored in earlier chapters of this study, as it seems to be "postulating a radical difference between societies characterized by 'meaning,' 'code,' 'territoriality,' and exchange, on the one hand, and societies (such as our own) of abstraction, of 'axiomatics,' of incommunicability, and accumulation, on the other."40 The implicit nexus between culture, religion, and language has also been pointed out by Andrei Znamenski, who noted that amongst American anthropologists, the German model of autonomous cultures led to a consistent focus on

\footnotetext{
$36 \quad$ Lawson and McCauley, 213.

37 Pals, Eight Theories of Religion, 341.

38 Geertz, "Religion As a Cultural System," 89.

39 Tomoko Masuzawa, "Culture," in Critical Terms for Religious Studies, ed. Mark C. Taylor (Chicago: University of Chicago Press, 1998), 8o.

40 Marc Augé, The Anthropological Circle: Symbol, Function, History, trans. Martin Thom (New York: Cambridge University Press, 1982), 83.
} 
"language and spirituality or, in other words, on the factors that made cultures distinct." ${ }^{11}$ Finally, Talal Asad also noted that Geertz's program for religion and culture brought with it the danger of opening up a "logical space for defining the essence of religion," by speaking of "two separate levels."42

Upon final analysis, the creation of this extrinsic, stable, and independent realm of symbols allowed thinkers of the discursive turn to find "support for their convictions about the immunity of features of religious experience."43 The turn to "discourse" and "text" brings with it a connotation that resembles strongly that of the "holy" and the "numinous," which we encountered in the insider-phenomenological approach. Like the realm of the sui generis sacred, the realm of the text is cut off from socio-political reality, autonomous, privileged over the historical world, and regarded to be the ultimate source of meaning. The radical alterity, which the insider-phenomenological approach located in cultures, religions, states of consciousness, and so forth, appears to have been transported into the domain of the text within the culturaldiscursive paradigm.

Now, if the cultural-discursive paradigm's nostalgia for alterity is ultimately analogous to that of thinkers like Otto or Eliade, then why does de Martino argue that it inaugurates a radically new type of ending, an apocalypse without eschaton? The answer is simple: The irredeemable end of the world is marked by a combination of two traits, in which the second one is a postmodern invention whose outlines were only adumbrated by the time of de Martino's death. On the one hand, the aforementioned persistent nostalgia for alterity, which can be regarded as a constant throughout much of the twentieth century; on the other hand, a profound doubt in the very possibility of such a true encounter with this alterity.

This doubt in the possibility of encountering alterity is primarily a result of the linguistic turn, which organically grew in parallel with the preoccupation

41 Znamenski, The Beauty of the Primitive, 6o. Similar comments have been made by Georg Iggers, who, in his analysis of the famous essay on "The Balinese Cockfight," demonstrated that Geertz not only saw culture as a semiotic system but that this system is also remarkably "integrated and stable, forming a whole." Iggers reminds his readers that "Geertz does not see the culture within the framework of social processes taking place in Balinese society; nor does he consider social divisions and social conflicts." Iggers, Historiography in the Twentieth Century, 125 .

42 Talal Asad, "The Construction of Religion as an Anthropological Category," in Genealogies of Religion: Discipline and Reasons of Power in Christianity and Islam, by Talal Asad (Baltimore: Johns Hopkins University Press, 1993), 47.

43 Lawson and McCauley, "Crisis of Conscience, Riddle of Identity," 213. 
with culture. ${ }^{44}$ Geertz's landmark study, The Interpretation of Culture, consists of essays written primarily in the 1960 s and proposes not only a relativistic conception of cultures, but also a symbolic approach, which might be best articulated in the famous definition of culture as "webs of significance [man] himself has spun." ${ }^{45}$ In his theoretically most revolutionary work, Geertz argued that "the culture of people is an ensemble of texts," which should be studied by means of a semiotic and interpretative approach. ${ }^{46}$ This method, which he called "thick description," would "aid us in gaining access to the conceptual world in which our subjects live so that we can, in some extended sense of the term, converse with them." ${ }^{47}$ As Hinrich Seeba has recently argued, Geertz's textualization of culture is therefore also linked to more radical forms of "fictional symbolizations of reality," which came to prominence in the literary turn. ${ }^{48}$

In discussing the linguistic turn, it is not only commonplace to mention continental influences like Michel Foucaul ${ }^{49}$ and Mikhail Bakhtin, ${ }^{50}$ but also another American book that belongs to its canon, namely Hayden White's Metahistory: The Historical Imagination in Nineteenth-Century Europe (1973). White's work, like Geertz's Interpretation of Cultures, published in 1973, demonstrates how the cultural-discursive paradigm had almost universal appeal in the humanities. In fact, unlike Geertz, Said, Fabian, or the Subaltern Studies Group, White was a historian by profession. White made two arguments to explain why language is relevant to the humanities. First, he believed that science does not have a direct and unmediated access to objective reality. Instead,

44 Gabrielle M. Spiegel, ed., Practicing History: New Directions in Historical Writing after the Linguistic Turn (London: Routledge, 2005).

45 Geertz, "Thick Description: Toward and Interpretive Theory of Culture," 5.

46 Clifford Geertz, "Deep Play: Notes on the Balinese Cockfight," in The Interpretation of Cultures: Selected Essays (New York: Basic Books, 1973), 452.

47 Geertz, "Thick Description: Toward and Interpretive Theory of Culture," 24.

48 Hinrich C. Seeba, "New Historicism und Kulturanthropologie: Ansätze eines deutschamerikanischen Dialogs," in Historismus am Ende des 20.Jahrhunderts: eine internationale Diskussion, ed. Gunter Scholtz (Berlin: Akademie-Verlag, 1997), 54.

49 Foucault is famous for having called attention to knowledge as power, to systems of domination and resistance, and to the role played by discourse. Michel Foucault, Les mots et les choses: une archéologie des sciences humaines (Paris: Gallimard, 1966); Michel Foucault, L'archéologie du savoir (Paris: Gallimard, 1969); Michel Foucault, Surveiller et punir (Paris: Gallimard, 1975).

50 Bakhtin is famous for inspiring literary readings of ethnography as a multivocal conversation and dialogue. Mikhail M. Bakhtin, Rabelais and His World, trans. Helene Iswolsky (Cambridge: M IT Press, 1965); Mikhail M. Bakhtin, The Dialogic Imagination: Four Essays, ed. Michael Holquist and Vadim Liapunov, trans. Vadim Liapunov and Kenneth Brostrom (Austin: University of Texas Press, 1981). 
our conception of the world is always embedded within structures of language that shape reality. As a consequence, so one proponent of this approach put it, "all the human sciences" become "interpretive by [their] very nature."51 Second, since language is structuring our interaction with reality, the neutrality of the researcher is just as illusory as the objectivity of reality. This brings us to the most radical form of thinking induced by the linguistic turn, namely the blurring of boundaries between science and literature, history and poetry, reality and fiction. These ideas are not only prominent in White's writings but also find expressions in the works of other French and American literary theorists during the 196 os and 70 s, such as Roland Barthes, ${ }^{52}$ Paul de Man, Paul Veyne, ${ }^{53}$ Michel de Certeau, ${ }^{54}$ and Jacques Derrida. The latter's famous axiom, which states that "there is nothing outside of the text" (il n'y a pas de hors texte") might just be the most concise way to sum up the literary turn's convictions. ${ }^{55}$

De Martino saw the first indications of this type of thinking already during the final years of his life. He invoked the term "language" (linguaggio) to warn that communication can become impossible because it is premised on an "encoded language (linguaggio cifrato) of which we have lost the key" 56 In other passages contained in his posthumously published work, de Martino explicitly cautioned that language can incite the collapse of the world and our relationship to it:

The apocalypse of the crisis is born from the progressive limiting of the horizons of the mundane workable (operabile) and provides testimony of a fall, a collapse, an estrangement (estraniazione), a chaoticization (caoticizzazione), an annihilation, or even an explosion of the real world. It is also a isolating (isolarsi), a closing (chiudersi), an intimizing (intimizzarsi) of the self. The language (linguaggio), in the broadest sense of an acoustic or visual sign of the relationship "I-world," tends to follow this collapse. Actually, language becomes itself collapsing (crollante) with the terminal perspective of silence and incommunicability (incomunicabilità)

$51 \quad$ Robert Darnton, "Preface to the Revised Edition of The Great Cat Massacre," in The Great Cat Massacre: And Other Episodes in French Cultural History, by Robert Darnton (1984; repr., New York: Basic Books, 20o9), xvii.

52 Roland Barthes, "Le Discours de l'histoire," Information (International Social Science Council) 6, no. 4 (August 1, 1967): 63-75.

53 Paul Veyne, Comment on écrit l'histoire (Paris: Seuil, 1971).

54 Michel de Certeau, L'écriture de l'histoire (Paris: Gallimard, 1975).

55 Jacques Derrida, Of Grammatology (1967; repr., Baltimore: Johns Hopkins University Press, 1976), 158.

56 De Martino, La fine del mondo, 73 . 
and no longer an intersubjective invocation. The sickness of the objects, the absurd consciousness, the lack of sense in the world, nausea, and so forth. ${ }^{57}$

Because this new crisis was born in a society that had full awareness of its own ability and responsibility, its autonomy and independence, its freedom and potential, it was not only an apocalypse without eschaton but also a crisis that was largely self-destructive (autodistruttiva). De Martino found evidence for this type of self-sabotaging throughout twentieth-century culture and dedicated his final years to study the sense of an ending in various contexts of his own world.

The "crisis" in the figurative arts, music, poetry, philosophy, and the ethical-political life of the West is a crisis to the extent that the rupture with a theological plan of history and with the sense which derived from it - the plan of providence, the plan of evolution, the dialectic plan of the idea-becomes no longer a stimulus for a new effort of descent into chaos and of anabasis towards order, but a fall into the hells without return. ${ }^{58}$

In order to bridge this chapter's anachronistic chasm, the inevitable gap between de Martino's analysis of the apocalypse in the early 196os and the rise of postmodernism in the decades that follow, it might be useful to recall a distinction introduced by Jonathan Boyarin, a contemporary scholar of Jewish thought. Boyarin describes a strikingly similar difference between "the 'historical' ancient apocalypses," which "fundamentally include an aspect of judgment leading to reward and punishment," on the one hand, and an "apocalypse without apocalypse," on the other. More pertinently, Boyarin follows de Martino by associating this second type of crisis with "the postmodern turn," by describing it as "the ultimate evacuation of any hope in meaning."59 Even though de Martino does not yet use the term postmodern, his description of the apocalypse without eschaton reads strikingly similar. Let us look at another example from his posthumously published notes:

57 De Martino, 335 .

58 De Martino, 471.

59 Jonathan Boyarin, "At Last, All the Goyim," in Postmodern Apocalypse: Theory and Cultural Practice at the End, ed. Richard Dellamora (Philadelphia: University of Pennsylvania Press, 1995), 43. 
In the religious life of humanity, the topic of the end of the world appears in various eschatological contexts, that is to say as a periodic cosmic palingenesis or as definitive redemption (riscatto) of the inherent evils of mundane existence. [...] In contrast to this religious reshaping (riplasmazione), the present cultural circumstance experiences the theme of the end outside of every religious horizon of salvation; as naked and desperate catastrophe of the mundane, the domestic, the territorialized (appaesato), the meaningful (significante), and the workable (operabile). [It does so] with a diabolic flavor for describing the dismantling (disfarsi) of that which is set up (configurato), the de-territorialization (spaesarsi) of the territorialized (appaesato), the loss of meaning of the meaningful (significante), the inoperability (inoperabilità) of the workable (operabile) ${ }^{60}$

As is well known, the literary turn received its most dominant expression in post-structuralist theory, which can be interpreted as a direct response to the binary oppositions that dominated the first half of the twentieth century. Indeed, the French theory of thinkers like Michel Foucault, Jacques Derrida, Jean-François Lyotard, Jean Baudrillard, or Gilles Deleuze emphasized aspects of play, hybridity, and ambiguity that have found no place in understandings of reality of the early twentieth century. Amongst the historians of religion, it was Russell T. McCutcheon, who tried to define postmodernism and its relationship to language in similar terms:

Although one would be hard-pressed to offer one definitive definition of postmodernism, we can at least suggest that it is a way of looking at the world which emphasizes playfulness and differences over rules and sameness; it stresses the metaphoric and slippery nature of language over the modernist, objective, factual understandings of how communication proceeds; it addresses the manner in which meaning is not something possessed by a word, an action, or an object as much as it is the product of a series of relations which comprise the word or the object. ${ }^{61}$

Equipped with this understanding of the literary turn that marked postmodern thought, it is now possible to offer a more definitive rationale for de Martino's fears of the end. While both paradigms are marked by fragmentation and separation, the proponents of the insider-phenomenological approach remain

6o De Martino, La fine del mondo, 468.

61 McCutcheon, The Insider/Outsider Problem in the Study of Religion, 9. 
convinced that they will find some sort of unity and an overarching model for reality, whereas the adherents of the cultural-discursive model have given up that belief and simply choose to embrace the chaos. ${ }^{62}$ To say it in the words of Wolfgang Kämmerer, "while back then the relativization generally provoked worries and caused a loss of orientation (Orientierungslosigkeit) even amongst the explicit supporters of historical thinking, today many advocates of postmodernity downright celebrate relativization." ${ }^{\prime 3}$ Evidence for this impossibility of ever fulfilling one's nostalgia and longing can also be found in later manifestations of the cultural-discursive paradigm, such as the Writing Culture Movement. Consider, for example, the following lines from the Prologue of Clifford's Routes: Travel and Translation in the Late Twentieth Century (1997).

These essays are written under the sign of ambivalence, a permanently fraught hope. They discover, over and over, that the good news and the bad news presuppose each other. It is impossible to think of transnational possibilities without recognizing the violent disruptions that attend 'modernization,' with its expanding markets, armies, technologies, and media. Whatever improvements or alternatives may emerge do so against this grim backdrop. Moreover, unlike Marx, who saw that the possible good of socialism depended historically on the necessary evil of capitalism, I see no future resolution to the tension-no revolution or dialectical negation of the negation. ${ }^{64}$

De Martino, passing away more than three decades before these words were written, anticipated the cognitive impossibility inherent in the culturaldiscursive paradigm with remarkable prescience. For him, the threat of the apocalypse was the result of a failure of communication, a logical consequence of "incommunicability" (incomunicabilità). As Carlo Ginzburg has recently noted, for de Martino, "the collapse of the world echoes the collapse of language." 65 Similarly, Paolo Virno, who apprises de Martino as "one of the few original philosophers twentieth-century Italy,"66 concluded that his con-

\footnotetext{
62 Harvey, The Condition of Postmodernity, 44.

63 Kämmerer, Friedrich Meinecke und das Problem des Historismus, 300.

64 James Clifford, Routes: Travel and Translation in the Late Twentieth Century (Cambridge: Harvard University Press, 1997), 10.

65 Ginzburg, "Genèses de La fin du monde de de Martino," 207.

66 Paolo Virno, "Natural-Historical Diagrams: The 'new Global' Movement and the Biological Invariant," in The Italian Difference: Between Nihilism and Biopolitics, ed. Lorenzo Chiesa and Alberto Toscano (Melbourne: Re.press, 2009), 140.
} 
ception of the apocalypse was ultimately linguistic and semantic in nature as one of its primary symptoms is "a progressive indetermination of speech." ${ }^{\text {"7 }}$

If de Martino was critical of the cultural turn, denouncing its abdication of our cultural homeland for a cultural alterity, he was much more severe in his condemnation of the linguistic turn. In order to actualize de Martino's distinctive reading of these two turns, it might be useful to recall the typology of modern nostalgia introduced by Svetlana Boym, who distinguishes between "restorative" and "reflective" nostalgia. If the former is profoundly rooted in a conviction of promoting "truth and tradition"-rather than nostalgia - the latter "dwells on the ambivalences of human longing and belonging and does not shy away from the contradictions of modernity." ${ }^{\prime 68}$ Dennis Walder, in his Postcolonial Nostalgias, similarly notes that "restorative nostalgia focuses on nostos, and tries in spite of history to reconstruct the lost home, or homeland; whereas reflective nostalgia thrives on algia, the longing itself, but 'wistfully, ironically, desperately." 69 This new type of nostalgia had dramatic consequences for our understanding of culture. In the French context, where the linguistic turn emerged with its greatest vigor, the German Kultur was no longer the locus of revitalizing escape into cultural alterity, but rather the relentless variation of permutating messages and endless discursive communication. Culture became signification without meaning, structure without content, language without history. Put differently, the key irregularity between the ontological and the cultural-discursive paradigms is one of self-awareness: Whereas the first hangs on to some model of ontological reality, albeit constructed by a constant struggle, the second paradigm distances itself from that realism by positioning itself on the level of the "linguistic event," as a deeper reality is not accessible anyway. ${ }^{70}$

If the "restorative" nostalgia of historicism gave birth to a whole series ofoftentimes problematic - palingenetic currents of thought that I summarized as the insider-phenomenological approach, the "impossible nostalgia" of the cultural-discursive paradigm has abandoned any hope for a new totalizing narrative. Thus, the crisis of 1965 was qualitatively different from that of 1918 as de Martino came to realize that the sense of belonging to a particular "village" or "country" (paese) was no longer an option. Put differently, the impossible nostalgia of postmodernism was so destructive because it committed two errors

\footnotetext{
67 Virno, 140.

68 Svetlana Boym, The Future of Nostalgia (New York: Basic Books, 2001), xviii.

69 Dennis Walder, Postcolonial Nostalgias: Writing, Representation and Memory (London: Routledge, 2011), 11.

$70 \quad$ Smith, Relating Religion, 274.
} 
simultaneously: First, it abdicated our culture out of a nostalgic longing for another ethnos; second, it gave up any hope at the recovery of this cultural alterity that could reinvigorate our own culture. What was so radically new about the apocalypse without eschaton is a type of double bind: A longing for renewal of cultural energy that was ultimately irredeemable.

\section{The Ethos of Transcendence of Life in Value as an Anticipatory Critique of the Discursive Turn}

Finding Value in Concreteness, Practice, and Morality Instead of Meaning, Interpretation, and Play

De Martino's response to this most abysmal of all crises is the "transcendental ethos of transcendence of life in value" (ethos trascendentale del trascendimento della vita nel valore). As its name already indicates, his final writings form the silhouette of a type of moral philosophy, whose intention is to transcend the crisis of meaninglessness by creating new values. In light of recent interpretations of his work, it is imperative to repeat that the Italian thinker, despite his growing sensibility for language, perspective, and the voice of the ethnographer, stood far away from the cultural-discursive model of thinking, particularly its tendency to associate reality and texts. In an article entitled "Sleepiness, Hunger, and Death Under the Stars" (1952), de Martino wrote about the dramatic scenes during his ethnographic encounters in the Italian South in direct juxtaposition to what it means to work on texts: "All of our persuasions have been broadly confirmed and deepened in the course of our journey, acquiring, through the human contacts that resulted, this concreteness (concretezza), which no written text could ever provide us." ${ }^{71}$ In a similar vein, Roberto Alciati recently suggested that "eating, drinking, or possessing clothes and a house cannot be if we do not presuppose a transcendence." "Unlike in the traditional Kantian meaning," so Alciati continues, "the Demartinian transcendental is not a gnoseological characteristic - that is the essential condition of possibility that allows for the attaining of necessary a priori knowledgebut rather a primordial impulse that allows the human being to detach itself from nature." 72

Similarly, while pundits like Gallini are right in noting that the tarantula must be understood as a cultural or mythical-ritual symbol, rather than simply

71 De Martino, "Sonno, fame, e morte sotto le stelle," 12.

72 Alciati, Roberto. "La religione civile di Ernesto de Martino." Studi e materiali di storia delle religioni 85 , no. 1 (2019): 285-317. p. 298. 
a biological organism, de Martino would have hardly agreed that the festivals associated with the spider-symbolism should be seen as texts. The Land of Remorse, for instance, is not concerned with the realm of the symbolism of the spider, but rather with the destiny of the people living through these ritualistic practices of possession and exorcism. This becomes particularly obvious in moments when he focuses on specific destinies of particular young women, such as the case of Maria of Nardò, ${ }^{73}$ whose father had died when she was a teenager. Raised in poverty by her aunt and uncle, she fell in love with a boy that the family did not approve of. Maria's life was a drama, which received a mythical and ritual expression in the following years when she was "bitten" by a tarantula spider and felt an impulse to dance. After having been married off to another man, the drama of her personal life received an outlet in her identity as a tarantata. She was re-bitten by the spider on a yearly basis, repeated the dance craze, which-accompanied by traditional tarantella music-would culminate in a public "performance" at the local Church. There, she would not only slowly be exorcised from the possessing spider spirit, but also celebrate a sacred marriage to St. Paul, a sort of patron saint of the spider-bitten women. This treatment of tarantism points to a key difference between the culturaldiscursive paradigm and de Martino's approach that would only grow more prominent in the last years of his life, namely the move away from language into the realm of practice and action.

Fabrizio Ferrari's claim that, for de Martino, "meaning" and "value" are the same,${ }^{74}$ must be critically re-evaluated. Although it is true that he identified the apocalyptic lack of meaning in semantic terms, de Martino's response is never linguistic in nature. In other words, the "value" that de Martino pursues, does not reveal itself in some sort of "semanticity," or linguistic meaning, but must rather be generated in a realm that is ultimately unaffected by language. "There exists," so the Italian thinker put it in The End of the World, "a transcendental principle that renders use (utilizzazione) and other valorizations (valorizzazioni) intelligible." "This principle," so he elaborated, "is the transcendental ethos of transcendence of life in value," "activity," "ethos, duty-to-bein-the-world (dover-essere-nel-mondo) for value," "the valorizing (valorizzante) activity that makes $(f a)$ the world, establishes it, and sustains it." ${ }^{75}$

73 De Martino, La terra del rimorso, $75 \mathrm{ff}$.

74 Fabrizio M. Ferrari, Ernesto De Martino on Religion, 103.

75 De Martino, La fine del mondo, 434. Ferrari's bias for a linguistic conception of de Martino's work is so pervasive that he not only translates valore with "meaning," but also uses the terms "signifying" for valorizzante and "define" for $f a$. 
Armed with this philosophical commitment to the ethos of transcendence, de Martino elaborated an alternative to both the restorative nostalgia of the insider-phenomenological tradition and the impossible nostalgia of the postmodernists. In response to the first, he remained steadfast in his belief that any relativist "critique" of our own culture necessarily requires a profound rootedness within our own cultural identity and its ethnocentric biases. Instead of postmodernism's despair and pessimism in light of the impossibility of true communication, de Martino attributed a much more positive function to this burden of the anthropologist. In the posthumously published notes, we read:

Without this quest for the challenge of the culturally foreign, without this pungent experience of the scandal raised by the encounter with ciphered humanities, and-most of all — without this guilt and this remorse towards the "separated brother" and the incoherent (irrelata) dispersion of cultures on our planet, the humanistic ethos of the ethnographic encounter is struck at its roots. It comes to lack the very fundamental condition that inaugurates the most striking task of anthropological research, namely the delicate and laborious interrogation and self-interrogation about the character and the reasons, about the origin, the structure, and the function of the cultural behavior of others. ${ }^{76}$

Borrowing a distinction introduced by Gianni Vattimo, we could contrast the "weak thought" of postmodernism with the "strong thought" of de Martino by basing it primarily on their differing attitudes towards reality and our interaction with it. ${ }^{77}$ The Italian philosopher was reluctant to translate the binaries that dominated modernity into hybrids that play themselves out on a textual level. His anthropology did not stand under the banner of something that is symbolic or hermeneutic, but everything that is engaged, political, and practical. It is striking that while anthropologists of the cultural-discursive paradigm move away from politics in response to the guilt of the ethnographic encounter, de Martino continued to be propelled towards political engagement. Thinkers like Geertz see their scholarship as a play of interpreting cultures, with his landmark study promoting a semiotic view of culture, a textual conception of reality, and a hermeneuticist and interpretative outlook on the epistemological orientation of anthropology. The ethos of transcendence, by contrast, involved a transition from language and culture to morality and values.

76 De Martino, 392.

77 Gianni Vattimo and Pier Aldo Rovatti, Il pensiero debole (Milano: Feltrinelli, 1983). 
Even more radically, while every culture (ethnos) has its own particular model of morality (ethos), de Martino believed that the ethical imperative cultivated by Western civilization stands out amongst the rest. Accordingly, it is only in the modern West that humanity has gained full awareness of its own historicity and its fundamental role as the creator of reality. In The End of the World, de Martino spoke of his culture as the "moral and civil leader (primato)" and gave it the responsibility of "cultural leadership."78 In his ethnocentric self-confidence and his emphasis on ethics, de Martino also stands in radical contradistinction to the paradigms of thinking about religion studied in this book. Wasserstrom, for example, notes how historians of religion were reluctant to focus attention on issues of morality. For Scholem, Corbin, and Eliade, he argues, "the ontical effectively replaced the ethical at the center of intellectual concern." ${ }^{79}$ Similar comments have been made by Preus, who writes that the proponents of the insider-phenomenological approach, "in reaction to the eighteenth-century habit of reducing ('true') religion to morality, [...] fixed a theological notion of 'the sacred' that has been very durable and popular until now: essential religion (which strongly implies 'authentic' religion), rooted in an apprehension of 'the holy', is utterly prior to either conceptual or moral formulation and elaboration." 80

A different variety of the withdrawal from the territory of ethics can be found in the cultural-discursive paradigm. In this orientation, the recognition that the ethnographic encounter is coextensive with power, domination, and pollution is culminating in a belief that anthropology can never be ethically neutral. As Gavin Flood noted, in the cultural-discursive paradigm, "the question of method [...] merges into the broader philosophical questions of the values inherent within Western culture, of ethical relativism and universalism, and into political questions of dominance and occlusion, especially as articulated in feminist and postcolonial critiques." ${ }^{81}$ If cultural relativism is an undeniable accomplishment inasmuch as the ethnographic encounter teaches us that our culture is not the only culture out there, it is problematic because it frequently turns into a philosophical position that can be summed up under the heading "anything goes." This type of position, so the philosopher and social anthropologist Ernest Gellner reminds us, claims that "knowledge or morality outside culture is $[\ldots]$ a chimera." ${ }^{2}$

78 De Martino, La fine del mondo, 397.

79 Steven M. Wasserstrom, Religion after Religion (Princeton: Princeton University Press, 1999), 225.

8o Preus, Explaining Religion, 200.

81 Flood, Beyond Phenomenology, 195.

82 Ernest Gellner, Postmodernism, Reason and Religion (London: Routledge, 1992), 73. 


\subsection{The Ethos of Transcendence as Dialectical Process: Between Loyalty to the Past and New Valorization in the Present}

As "history to be made," de Martino's science operated both retrospectively and prospectively. Oriented towards our past, science means loyalty and stands for the fact that we can never forget where we belong, as this situational background will impact our perception of the present-whether we want it to or not. In its futural dimension, by contrast, science is the invitation to take a position, to decide, to break with the past, and to make history in the present. It is in this initiative to break with what is given that de Martino's reflections on ethics might actually reveal surprising affinities with one of the greatest exponents of the cultural-discursive paradigm, namely Jacques Derrida. Late in his career, Derrida became increasingly interested in ethical decision-taking as a process that decisively transcends predetermined knowledge. A few months before his death, in an interview with L'Humanité, a French daily newspaper with close links to the French Communist Party, Derrida explained:

[...] if one understands ethics as a system of rules, of moral norms, then I am not proposing a morality. What I am interested in, in fact, are the aporias of ethics, its limits. [...] All of this implies a thinking of decision: responsible decision has to endure the experience of the undecidable rather than just crossing over or going over it. If I know what I must do, I do not make a decision, I apply a knowledge, I unfold a program. For there to be a decision, I must not know what to do. [...] The moment of decision, the ethical moment, if you will, is independent from knowledge. It is when "I do not know the right rule" that the ethical question arises. ${ }^{83}$

In terms that remind us of de Martino's imperative to "take sides" (prendere partito), Derrida highlighted the importance of the "un-ethical moment of ethics, the moment in which I do not know what to do, when no norms are available to me, when I do not have to have norms available, but when I have to act, take on my responsibilities, take sides (prendre parti)." 84 This being said, de Martino's thinking towards the end of his life, infused with a modernist and ethnocentric ethos that is foreign to Derrida's work, maintained a dialectical dynamic between the need to transcend and the maintaining of loyalty to our cultural homeland, which is always already available.

83 Jérôme-Alexandre Niesberg, "Jacques Derrida, penseur de l'évènement,"” interview in L'Humanité, January 28, 2004, www.humanit.fr.

84 Niesberg. 
The "world" is always given in its communal totality to be reclaimed in the specificity and the singularity of a valorization. It is always removed in habitual patterns and within this more or less anonymous and socialized experience, it is traced as an intimate and personal figure that emerges out of the one's own valorizing initiative. But the given, the habitual, the obviousness of the world are possible as immediate faithfulness to initiatives of past generations [...]. They are the ground and the homeland upon which the personal task of today is rising. [...] It is only through this anonymous domesticity of the world that it is possible to prepare oneself for its recovery, always reinventing itself in "my" original, singular choices. The individual can "start over" a certain aspect of the worldand he always restarts it as if he were the first man to begin, to be a man for the first time ever - only if all other aspects function momentarily as background. This background, in turn, implicitly includes human meaning, a work of humanization incurred in the obvious domesticity of the environment, a fundamental testimony of togetherness, of quiet workable collectivity extending in space and time..$^{85}$

De Martino illuminates the dialectics of the ethos of transcendence-made up of an oscillation between faithfulness to the past one inherits, on the one hand, and the fresh valorization in the present moment, on the other-through his reflections on walking, which is part of what he described as the "domestication" (domesticazione) of the body. On the one hand, "walking in an upright position [...] does not require concentration of conscious attention" because "we are accompanied and sustained by this history and by the efforts, by the research, by the inventions, and by the learning that it entails." ${ }^{86}$ On the other hand, walking is an individual practice that needs to be actualized in the present every time we start moving.

In simply walking, the human body is not given but continuously and completely put into question (messo in causa) and reclaimed (ripreso)

85 De Martino, La fine del mondo, 648. For another translation see: Alfonso M. Di Nola, "How Critical Was de Martino's 'Critical Ethnocentrism' in Southern Italy?," in Italy's “Southern Question": Orientalism in One Country, ed. Jane Schneider (Oxford: Berg, 1998), 162. The idea of the dialectic is central to the argument of Amalia Signorelli, one of the few outspoken critics of the association between de Martino and postmodern thought. She notes that "while, amongst the contemporary neo-relativists, the encounter with the others is theorized in situational and semiotic-communicative terms, in de Martino the encounter is always existential and at the same time dialectic."

De Martino, Scrittifilosofici, 127-28. 
for the purpose of this particular utilization that is the moving over the ground by letting the arms and hands swing freely for other useful (utilizzatrici) valorizations. Now, this very particular putting into question and reclaiming, putting in effort (impegnarsi) and leaving oneself available (lasciarsi disponibile) realizes itself in the upright position in walking. It constitutes a transcending (trascendimento) of the body. When one walks, one invokes a technique and readjusts it to the circumstance. The fact that walking is mostly executed "without thinking about it" - with the mind directed elsewhere [...] — does not mean that we are not gradually presentifying our walking-style. It only means that for us, the dutyto-be-there (doverci essere) has become a duty (dovere) so elementary, a transcending (trascendimento) of the body so easy, a discovery so inaugural, to make it possible to be there for other transcendences (trascendimenti) and for other discoveries even while we are walking [...]. For example, while we walk, we can also follow the thread of a poetic phantasm or of a thought. Walking is a labor based on value, a labor that-like any other work for value-liberates us from the givenness of the body, putting it into question and reclaiming it, and makes us emerge by virtue of this recovery (ripresa). ${ }^{87}$

Walking is thus both an "obvious" practice, grounded in a long implicit history that serves as cultural background and a history which is nonetheless always "picked up every time when humans walk."88 Appropriately, de Martino also invoked the earthquake trope in these philosophical notes in the years before his death. Discussing the "characteristic gait" of shepherds and farmers, horse riders and men of arms, Maori women and prison inmates, he also remembered his own experiences with his greatest philosophical teacher, Benedetto Croce: "Amongst the personal styles of walking, every one of us remembers the old Croce, with his slow and solemn stride, slightly dragging the leg he fractured in the earthquake of Casamicciola." ${ }^{89}$ While the earthquake posed a great risk for Croce, he survived it and moved beyond it. Not only that, it is precisely because he transcended the catastrophe that he is marked by it for the rest of his life. Although the experience is over, its reverberation has left its imprints on a physical level.

Further, just as the initial crisis reverberated in Croce's physical existence with every step he took, the risk of the crisis of the presence remained a

\footnotetext{
87 De Martino, 127-28.

88 De Martino, $127-28$.

89 De Martino, 130.
} 
continued threat. In this sense, the earthquake and its continued resonance in Croce's gait is comparable to the cultural development, which moved from the crisis of the shaman in the world of magic - birth moment of the selfthrough Christianity, the Renaissance, the Age of Enlightenment and so forth. Ultimately, this procession leads into the time of de Martino, during which he regarded the promotion of the ethos of transcendence as the most important goal. However, even then, the presence is not in a safe haven from the crisis of loss as the original vulnus is existentially embedded within the fabric of the human psyche and culture. And so, the project of protecting the presence remains a contemporary mission. If the presence is "the first vital human good," de Martino observes in "Religious Phenomenology and Absolute Historicism," it can nonetheless "run the risk of being lost in certain historical conditions." ${ }^{90}$ Based on more personal notes from late in his life, we can infer that de Martino also sought to relate religion to the ethos of transcendence. Using the example of a cripple walking on a crutch, he applied his dialectical thinking in such way so as to argue that religion is both something to be overcome and yet something universally necessary.

If religious life is a technical system that protects from the risk of losing the capacity to be in any possible civil history and that opens up anew (ridischiude) the various workings (vario operare) that a crisis without horizon would compromise, [then] religious freedom proves to be firmly established in the society in which modern civilization articulates itself. Who would break the crutches of a cripple with the argument that a normal walk does not require crutches? What we need to do is to reduce, as much as possible, the accidents and diseases for which the number of cripples is so high that the request for and use of crutches becomes inevitable. In other words, the challenge could be to replace the means that are the crutches with a more effective orthopedic technique. ${ }^{91}$

The analogy of religion as a crutch that can be gradually replaced with a combination between social prophylaxes and a more sophisticated orthopedic treatment, shows that de Martino, during the 196os, understood the ethos of transcendence as a post-religious response to the apocalypse. In The End of the World, we also encounter a more positive appreciation of our original "homeland" as the warmth of the maternal mother, which is a basic condition that

90 De Martino, "Fenomenologia religiosa e storicismo assoluto," 1995, 59.

91 De Martino, Vita di Gennaro Esposito, Napoletano, 25. 
we will never forget. Yet even here, this most primordial homeland represents a state of being that can and should be transcended as we grow up.

The warmth of the maternal mother was the first homeland we experienced and the world appeared for the first time within the confines marked by this contact. Beyond these confines, the possession of our body started to define itself and the affectionate operability of the maternal body extended itself. We conquered our mouth by sucking milk as our lips of nursing children were the first school of being-in-the-world. Then the feeling of the body in the world started to constitute itself through the caresses of a hand that measured its surface, through the reassuring breath, the kissing mouth, the smiling face, the coddling voice of the mother. From then on, our body was destined to become obviously ours and to preserve itself in this obviousness (ovvietà) to the extent in which it safeguarded (custodiva) the treasure buried by these elementary somatic and cosmogonic memories. From then on, [it also] continued to participate in the diverse and always renewed transcending (transcendere) to which the human destiny incessantly calls us. ${ }^{92}$

De Martino, La fine del mondo, 618. 